A USGS Zonal Table for the Upper Cretaceous Middle Cenomanian-Maastrichtian of the Western Interior of the United States Based on Ammonites, Inoceramids, and Radiometric Ages

Open-File Report 2006-1250 


\section{A USGS Zonal Table for the Upper Cretaceous Middle Cenomanian-Maastrichtian of the Western Interior of the United States Based on Ammonites, Inoceramids, and Radiometric Ages}

By William A.Cobban, Ireneusz Walaszczyk, John D. Obradovich, and Kevin C. McKinney

Open-File Report 2006-1250 


\section{U.S. Department of the Interior DIRK KEMPTHORNE, Secretary}

\section{U.S. Geological Survey \\ Mark D. Myers, Director}

\section{U.S. Geological Survey, Reston, Virginia: 2006}

For product and ordering information:

World Wide Web: http://www.usgs.gov/pubprod

Telephone: 1-888-ASK-USGS

For more information on the USGS--the Federal source for science about the Earth, its natural and living resources, natural hazards, and the environment:

World Wide Web: http://www.usgs.gov

Telephone: 1-888-ASK-USGS

Any use of trade, product, or firm names is for descriptive purposes only and does not imply endorsement by the U.S. Government.

Although this report is in the public domain, permission must be secured from the individual copyright owners to reproduce any copyrighted materials contained within this report.

Suggested citation:

Cobban, W.A., Walaszczyk, Ireneusz, Obradovich, J.D., and McKinney, K.C., 2006, A USGS zonal table for the Upper Cretaceous middle Cenomanian-Maastrichtian of the Western Interior of the United States based on ammonites, inoceramids, and radiometric ages: U.S. Geological Survey Open-File Report 2006-1250, 45 p. 


\section{A USGS Zonal Table for the Upper Cretaceous Middle Cenomanian- Maastrichtian of the Western Interior of the United States Based on Ammonites, Inoceramids, and Radiometric Ages}

William A. Cobban ${ }^{1}$, Ireneusz Walaszczyk ${ }^{2}$, John D. Obradovich, and Kevin C. McKinney $^{1}$

${ }^{1}$ U.S. Geological Survey, Denver Federal Center, MS 980, Denver, CO. 80225. USA. Email: kcmckinney@usgs.gov. ${ }^{2}$ Faculty of Geology, University of Warsaw, Al. Zwirki I Wigury 92, PL-02-089 Warszawa, Poland. E-mail: i.walaszcyk@uw.edu.pl.

\section{Introduction}

This provisional table (fig. 1) is based mainly on the molluscan fossil record of the central and northern parts of the Western Interior of the United States. Some of the ammonite zones are known in Europe, such as Watinoceras devonense, Collignoniceras woollgari, Prionocyclus germari, Scaphites hippocrepis, Didymoceras stevensoni, and Didymoceras cheyennense, whereas more than one-half of the inoceramid zones are known also in Europe. A few of the ammonite zones are known from only a few localities, but the diagnostic species may occur in abundance. Among these are the zones of Acanthoceras granerosense, A. bellense, Dunveganoceras problematicum, Burroceras clydense, Watinoceras devonense, Collignoniceras praecox, and Scaphites mariasensis. All fossils listed in the table are in the national collection housed in Building 810 at the Federal Center, Denver, Colo. 
This zonation is based on field work by U.S. Geological Survey geologists and their collections of fossils. There are other Western Interior zonations by paleontologists outside the USGS, especially the many works of E.G. Kauffman and associates (Kauffman et al., 1994).

figure 1 (chart attached to page 47 at the end of volume) 
The present zonation was founded mainly on the extensive collection of fossils made by the following USGS personnel, in alphabetical order: C.E. Erdmann, J.R. Gill, E.R. Landis, E.A. Merewether, C.M. Molenaar, F. Peterson, J.D. Powell, J.B. Reeside, Jr., and G.R. Scott. Special thanks go to Stephen C. Hook (Atarque Geologic Consulting, Socorro, N. Mex.) for much cooperative work with Cobban on the Cretaceous stratigraphy and fossils of New Mexico and Trans-Pecos Texas, while Hook was employed by the New Mexico Bureau of Mines and Mineral and Mineral Resources during 1976-1981.

Different molluscan zonations of Upper Cretaceous ammonites and inoceramids have been shown in tables in numerous publications beginning with the broad zonation of Stephenson and Reeside's (1938) 10 zones to the present one of 67 zones. The zonation begins with a great transgression of the epeiric sea early in the middle Cenomanian and ending in the late Maastrichtian. In general, each successive zonation was a revision of the next older one and usually added more refinement by the subdivision of zones or the recognition of new zones. In the following discussion on the construction of the present zonation, only the more important changes are treated. For simplicity, each zone is designated by a single name of a species. Subspecies names are not used, although some of the species in the table were considered as subspecies in earlier tables (Hook and Cobban, 1981; Cobban and Hook, 1983; Cobban, 1984, 1988b). In the present report, the words ammonite and inoceramid are applied both as a noun and an adjective, which seams to be in general use these days. 


\section{Constructing the Zonation}

Much of the early stratigraphic work in the Western Interior of the United States was along the Missouri River, where steamboat travel from St. Louis to Fort Benton was available. The general order of much of the Cretaceous sedimentary rocks was determined in the 1850s. At first the formations were numbered 1 to 5 from oldest to youngest. In 1861 F.B. Meek and F.V. Hayden gave the following geographic names to the sequence (Waage, 1975, p. 60):

\begin{tabular}{|c|c|c|}
\hline Eocene & & Fort Union or Great Lignite Group \\
\hline Cretaceous & $\begin{array}{l}\text { Upper Series } \\
\text { Lower Series }\end{array}$ & $\begin{array}{l}\text { Formation No. 5. Fox Hills beds } \\
\text { Formation No. 4. Fort Pierre Group } \\
\text { Formation No.3. Niobrara Division } \\
\text { Formation No.2. Fort Benton Group } \\
\text { Formation No.1. Dakota Group }\end{array}$ \\
\hline Coal Measures & & \\
\hline
\end{tabular}

In 1876 Hayden proposed the name Colorado group for the strata between the Dakota and Fox Hills groups along the Front Range in Colorado. C.A. White (1878) emended this definition to include only the Fort Benton and Niobrara groups. Later G.H. Eldridge (1888, 1889) gave the name Montana group to rocks in central Montana equivalent to the Fort Pierre Shale and Fox Hills Sandstone of the Dakotas. Fossils reported on in the late 
1800s were usually assigned to some one of the few named formations, such as "upper part of the Fort Pierre group” (Meek, 1876a), or the fossils were grouped under a formational name such as “Colorado fauna” or "Montana fauna” (Stanton, 1894, 1909). During the 1920s Reeside authored several papers on Cretaceous molluscan faunas from the Western Interior in which he related many of the species to the European stages of the Cretaceous. These papers included important works on ammonite faunas (Reeside, 1927a,b).

Stephenson and Reeside (1938), in comparing the Upper Cretaceous of the Western Interior and Gulf regions, recognized 10 molluscan zones in the Western Interior, of which most of their record was in the pre-Campanian part. Their zonation is summarized in the following illustration (fig. 2) based on their original figure 3 and adjacent pages. 


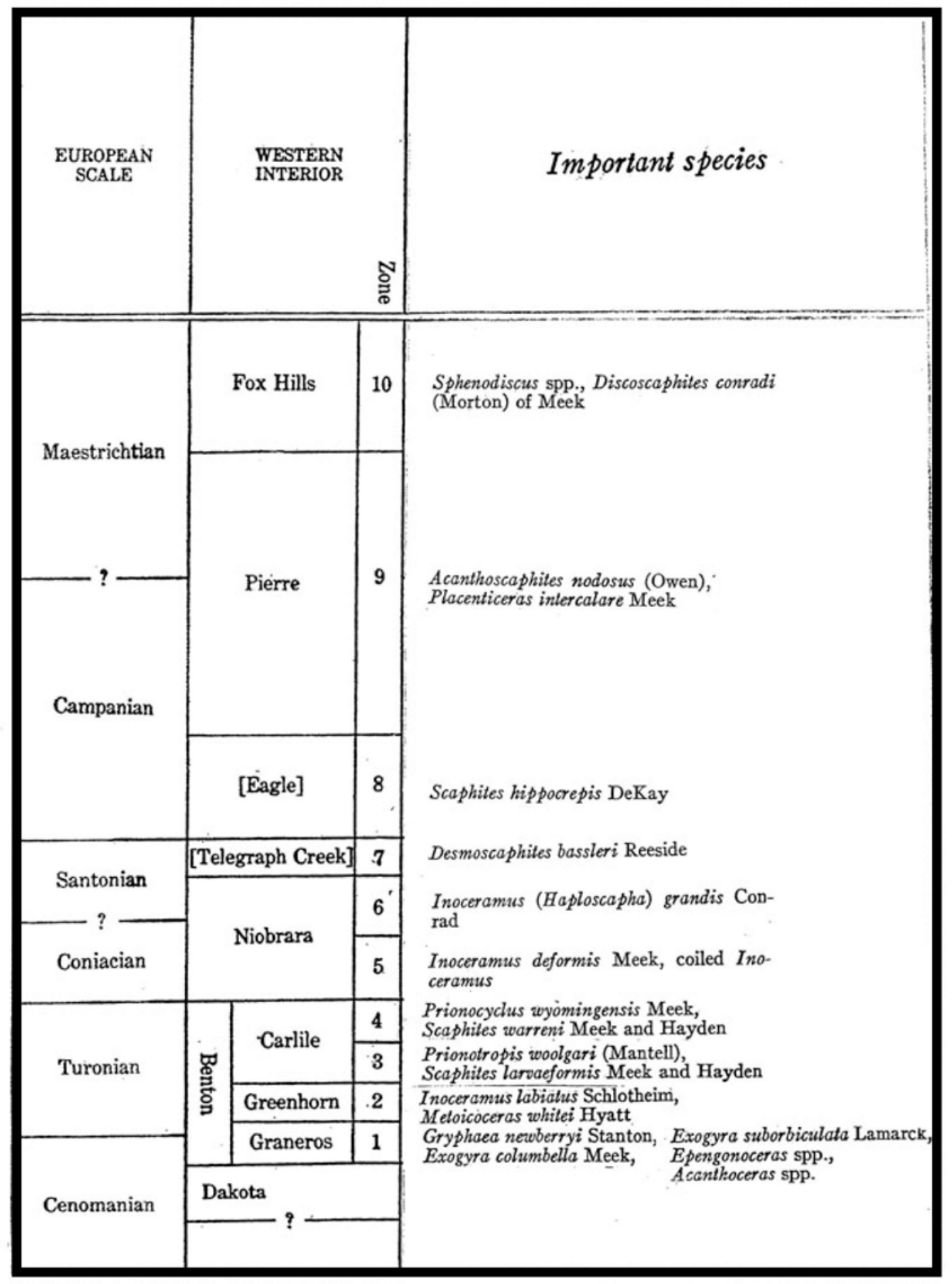

Figure 2. Upper Cretaceous stages, Western Interior formations with fossil zones 1-10, and important molluscan species (modified from Stephenson and Reeside, 1938, p.163638). Reeside repeated this zonation in 1944 (Reeside, 1944). 
Strata of Colorado age (Cenomanian-Santonian) in Montana and in the Black Hills area were investigated by Cobban in the 1940s. A sequence of 20 zones was established (Cobban, 1951a, fig. 2). This zonation was applied by Cobban and Reeside (1952) in their Geological Society of America’s correlation of Cretaceous formations of the Western Interior, Chart 10b. In addition to the Colorado Group, the chart included nine ammonite zones in the Montana Group. The Upper Cretaceous part of the chart is shown below (the zonation was repeated by Reeside, 1957, table 1). 


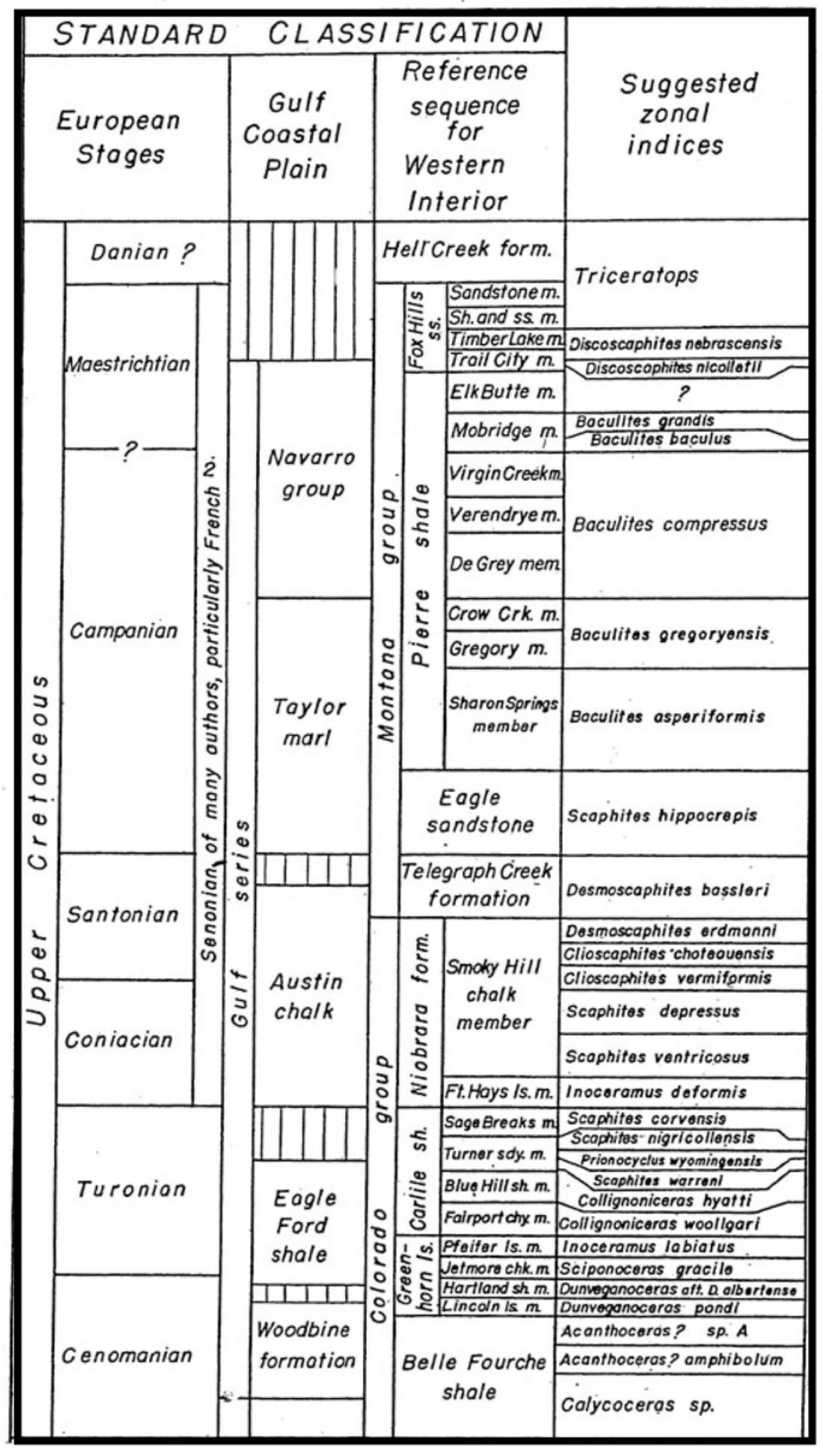


Figure 3. Upper Cretaceous stages and formations of the Gulf coastal plain and Western Interior with fossil zones mostly from northern part of Western Interior. Part of chart 10b of Cobban and Reeside (1952).

Extensive field work by G.R. Scott and Cobban in the late 1950s in the Pierre Shale mainly along the Front Range area of Colorado made possible a more refined zonation of the Montana Group. The three Campanian zones of Baculites asperiformis, $B$. gregoryensis, and B. compressus of the GSA chart were subdivided into the following 13 zones (Scott and Cobban, 1959; see also Cobban, 1958a,b):

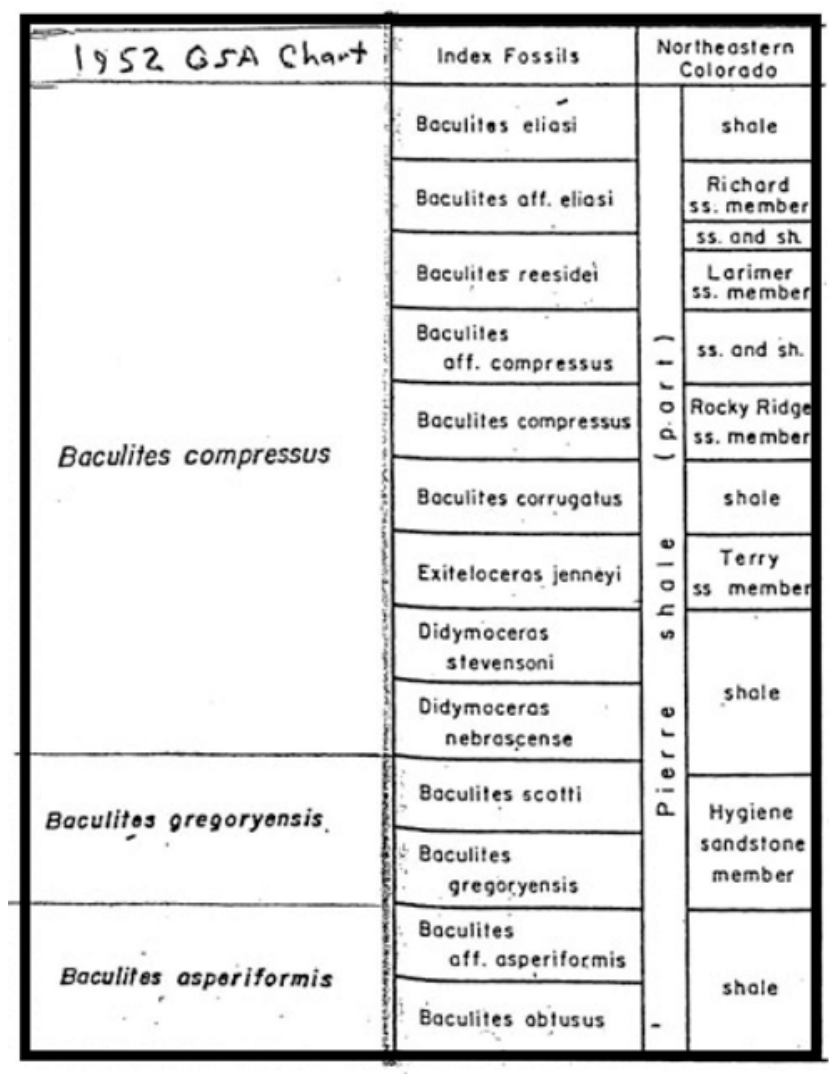

Figure 4. Campanian zones of Baculites asperiformis-B. compressus of Cobban and Reeside (1952, chart 10b) and ammonite zonation of Pierre Shale of northeastern Colorado. Modified from Scott and Cobban (1959, fig. 3). 
The baculitid sequence was refined further following a taxonomic study by Cobban (1962 a,b).

In the early 1960s, H.A. Tourtelot was in charge of a geochemical investigation of the Pierre Shale of the northern Great Plains and the equivalent stratigraphic rocks farther west. J.R. Gill (1922-1972), a superb fossil collector, did much of the field work of this project. The following sequence, based mainly on Baculites, was determined for the Montana Group (Gill and Cobban, 1965).

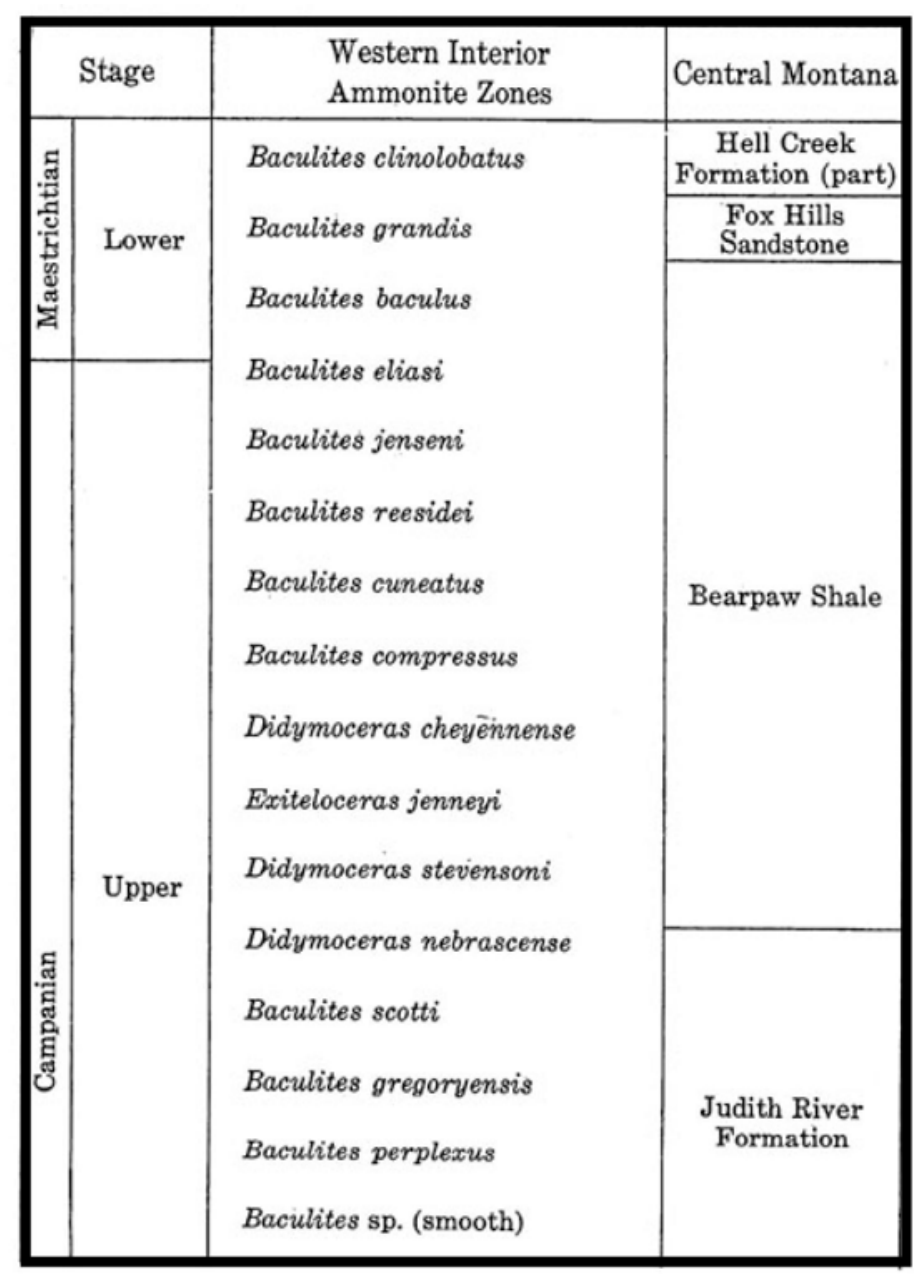

Figure 5. Campanian and lower Maastrichtian ammonite zonation and formations in central Montana. From Gill and Cobban (1965, fig. 3, in part). 
Baculites reduncus, a curved species, was later found to occupy a position between $B$.

gregoryensis and B. scotti (Cobban, 1977).

A study of the early Campanian ammonite Scaphites hippocrepis (DeKay) and the late Santonian and earliest Campanian S. leei Reeside revealed that both species occurred as three chronologic subspecies each numbered I-III (Cobban, 1969). Scaphites

hippocrepis first appeared as zones I to III on a chart by Gill et al., 1970, table 1; see also Gill and Cobban, 1973, fig. 12).

By the early 1960s, a zonation of the Colorado Group was fairly well established. The sequence was shown well in a study of the ammonite family Binneyitidae.

\begin{tabular}{|c|c|c|}
\hline Stages & Zone fossils & Binneyitidae \\
\hline Santonian (lower) & Clioscaphites vermiformis & Binneyites rugosus \\
\hline Coniacian & $\begin{array}{l}\text { Scaphites depressus } \\
\text { Scaphites ventricoșus } \\
\text { Inoceramus deformis }\end{array}$ & $\begin{array}{l}\text { Binneyites parkensis } \\
\text { Binneyites nodosus }\end{array}$ \\
\hline Turonian & $\begin{array}{l}\text { Scaphites corvensis } \\
\text { Scaphites nigricollensis } \\
\text { Prionocyclus wyomingensis } \\
\text { Scaphites warreni } \\
\text { Collignoniceras hyatti } \\
\text { Collignoniceras woollgari } \\
\text { Inoceramus labiatus } \\
\text { Sciponoceras gracile }\end{array}$ & $\begin{array}{l}\text { Binneyites aplatus } \\
\text { Binneyites carlilensis } \\
\text { Borissiakoceras sp. } \\
\text { Borissiakoceras cf. orbiculalum }\end{array}$ \\
\hline Cenomanian & $\begin{array}{l}\text { Dunveganoceras albertense } \\
\text { Dunveganoceras conditum } \\
\text { Dunveganoceras pondi } \\
\text { Acanthoceras? wyomingense } \\
\text { Acanthoceras? amphibolum } \\
\text { Borissiakoceras compressum }\end{array}$ & $\begin{array}{l}\stackrel{?}{?} \\
? \\
\text { Borissiakoceras orbiculatum } \\
\text { Borissiakoceras reesidei } \\
\text { B. compressum, Johnsonites sulcatus }\end{array}$ \\
\hline
\end{tabular}

Figure 6. Ammonite zones for the part of the Upper Cretaceous and position of Binneyites and Borissiakoceras (Cobban, 1961, table 1). 
A little later, the ammonite Clioscaphites saxitonianus (McLearn) was determined to form a zone between C. vermiformis and Scaphites depressus (Scott and Cobban, 1962), and the ammonite Acanthoceras?wyomingense (Reagan) was placed in Plesiacanthoceras (Haas, 1964).

The stratigraphy and paleontology of the Niobrara Formation in the Pueblo area of Colorado was investigated by Scott and Cobban (1964). Part of their table 3 is shown here. 


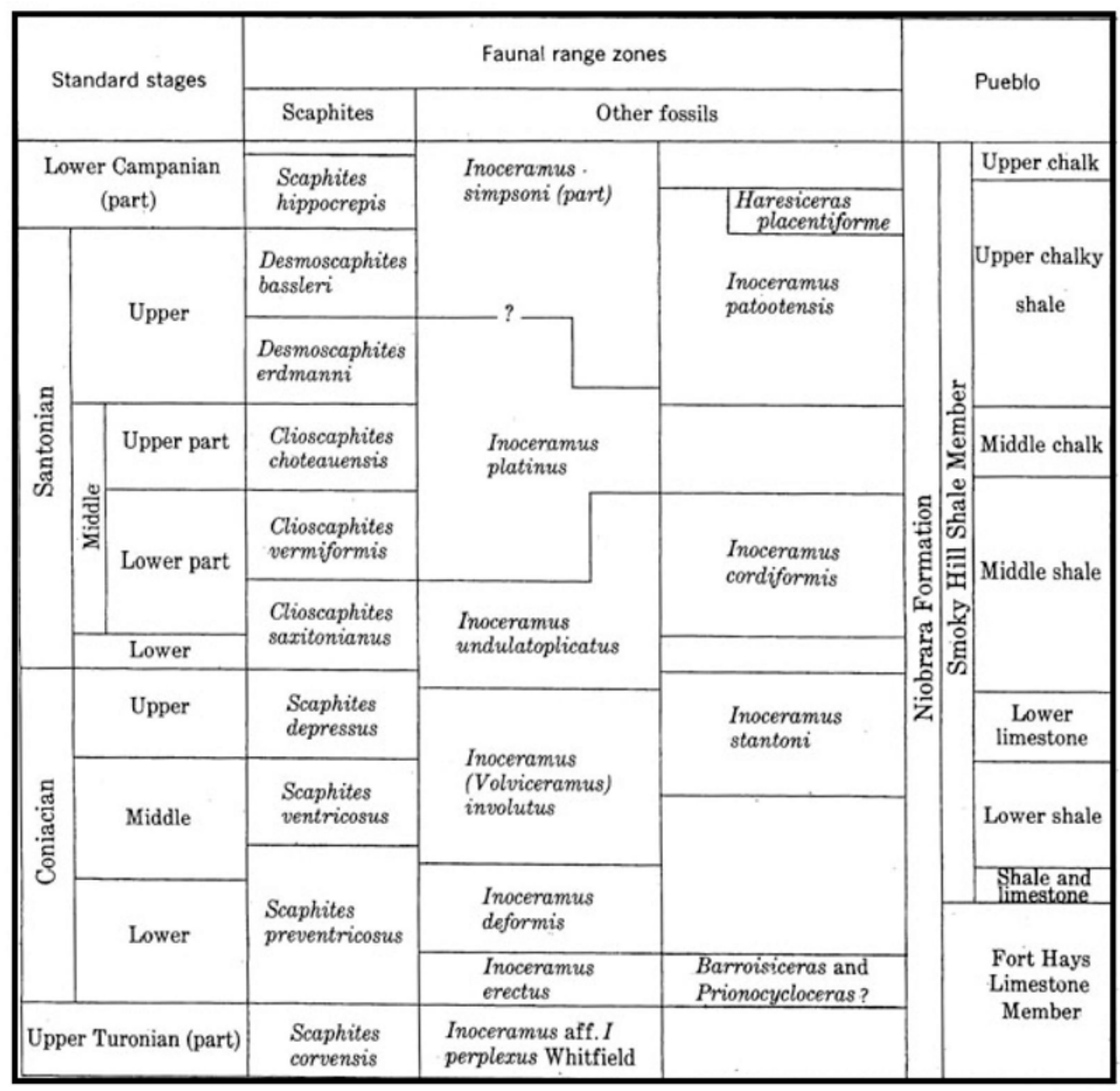

Figure 7. Upper Turonian-lower Campanian stages, molluscan fossil zones, and formations of the Pueblo, Colorado, area. From Scott and Cobban (1964, part of table 3). This was an early attempt to integrate ammonite and inoceramid zonation.

Inoceramus aff. I. perplexus is now considered Mytiloides scupini (Heinz), Inoceramus erectus and I. deformis are now placed in Cremnoceramus, I. stantoni is considered a junior synonym of I. undabundus, I. cordiformis is assigned to Cordiceramus, I. platinus is a nomen nudum (poorly defined species), and I. patootensis is probably 
Sphenoceramus lundbreckensis. The ammonites Barroisiceras and Prionocycloceras? are Forresteria.

In the course of mapping the geology of many quadrangles in the eastern one-half of Colorado, G.R. Scott refined the stratigraphic units and collected numerous fossils. The middle Cenomanian Graneros Shale and the upper Cenomanian and lower Turonian Greenhorn Limestone received much attention that resulted in Professional Paper 645 (Cobban and Scott, 1972). The middle Cenomanian into the base of the middle Turonian rock sequence and fossil zones of the Pueblo area were given in the following table:

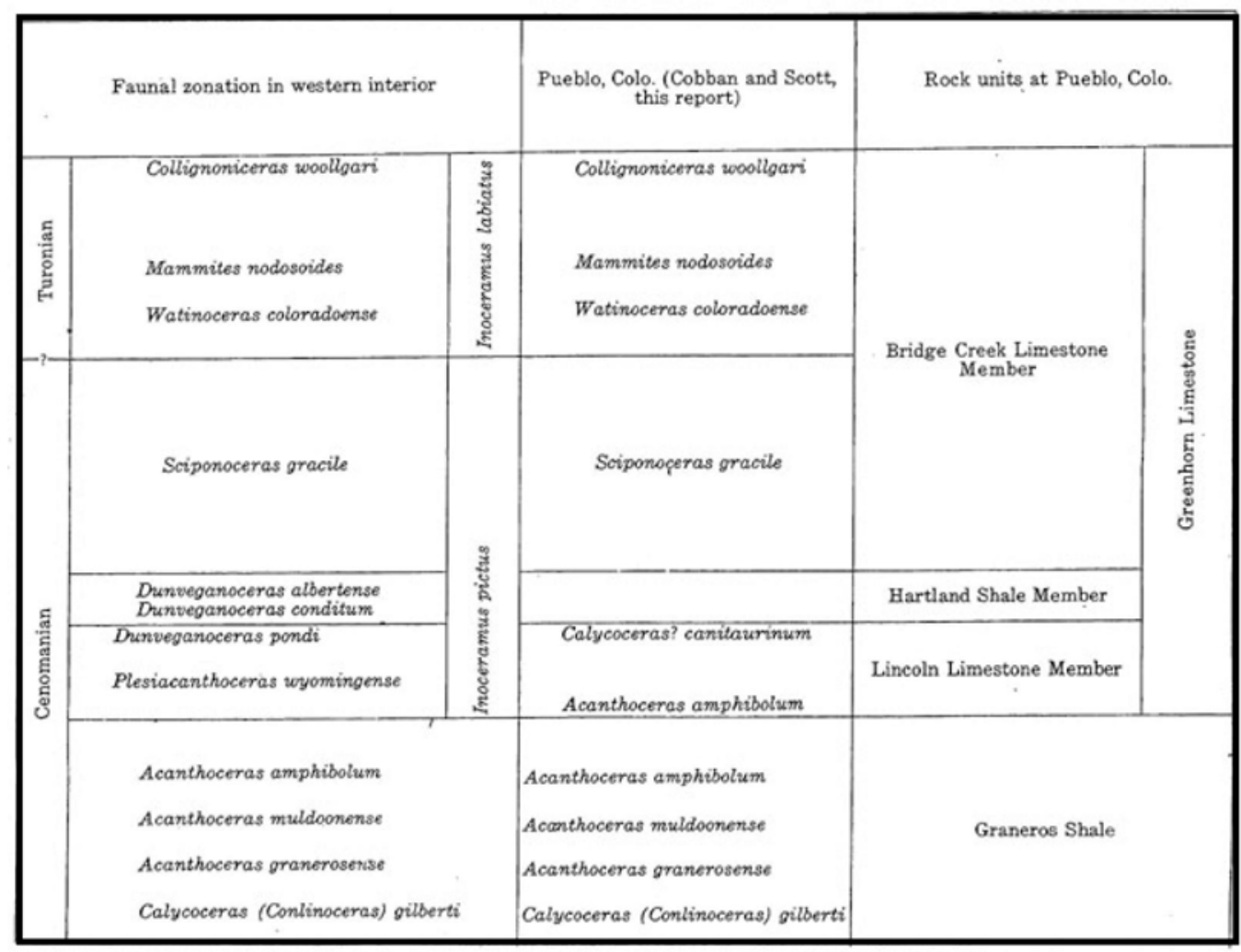


Figure 8. Ammonite zonation of Cenomanian and part of Turonian of the Western Interior and Pueblo, Colorado, area, and the rock sequence at Pueblo (Cobban and Scott, 1972, table 4).

Calycoceras (Conlinoceras) gilberti Cobban and Scott was a new name given to the Calycoceras sp. of previous reports. Two new species of ammonites, Acanthoceras granerosense and A. muldoonense, marked middle Cenomanian zones between $C$. gilberti and A. amphibolum. Dunveganoceras pondi (Haas), from the base of the upper Cenomanian of Wyoming and Montana, was not found in the Pueblo area, but Calycoceras? canitaurinum (Haas), restricted to the pondi zone, is common at Pueblo. Seiponoceras gracile (Shumard), a straight ammonite and the immediate ancestor of Baculites, was believed to occupy the rest of late Cenomanian time. The zones of Watinoceras coloradoense Henderson, Mammites nodosoides (Schlüter), and Collignoniceras woollgari (Mantell), were assigned to the Turonian.

Calycoceras (Conlinoceras) gilberti appeared as a zone in many publications during the decade following the Cobban and Scott Pueblo paper. In that paper (Cobban and Scott, 1972, p. 62), attention was drawn to the close resemblance of gilberti to the two ammonites from the Woodbine Formation of Texas described by Walter Adkins (1928) as the new species Metacanthoceras? tarrantense and Acanthoceras wintoni. Cobban and Scott believed the two Texas fossils were one species (tarrantense) and assignable to Calycoceras (Conlinoceras). Cobban and Hook (1983, table 1) raised 
Conlinceras to full generic rank and replaced gilberti by tarrantense because the latter was more widely distributed.

The middle Cenomanian ammonite Acanthoceras alvaradoense Moreman was added to the zoned sequence between A. muldoonense and A. amphibolum (Merewether, et al., 1975), but later it was treated as a subspecies of A. amphibolum (Cobban and Hook, 1983, table 1; Cobban, 1984, fig. 2), and after 1984, A. alvaradoense was no longer used as a zone.

The ammonite Nigericeras scotti Cobban was added to the lower Turonian zonation just below a zone of Watinoceras coloradoense-Vascoceras birchbyi (Cobban and Hook, 1979, fig. 1), and the ammonite Neocardioceras juddii (Barrois and Guerne) was added at the base of the Turonian just beneath the scotti zone (Hook and Cobban, 1981, fig 1). An investigation of the Cenomanian and Turonian strata and fossils of England by Wright and Kennedy (1981) revealed that the juddii zone marked the top of the Cenomanian, and, accordingly, Cobban and Hook (1983, table 1) raised the Cenomanian boundary to fit the European placement. The types of $N$. scotti came from a bed of limestone in the Bridge Creek Member of the Greenhorn Limestone in southeastern Colorado (Cobban, 1972). Collections made from that locality show that the species occurs a little higher in the formation than $N$. juddii. $N$. scotti is now considered the top of the Cenomanian in the Western Interior (Cobban, 1988a, fig 13; Kennedy and Cobban, 1990, fig. 3). It should be noted that $N$. scotti has been found only in a single bed at three localities in southeast Colorado and, questionable, from a specimen in southwest 
New Mexico. According to Gale (1989), the N. juddii Zone involves perhaps $300 \mathrm{kyr}$ of time.

Acanthoceras bellense Adkins (1928), a species described from the basal part of the Eagle Ford Formation of Texas, was found later in the Belle Fourche Shale of the Black Hills area in eastern Wyoming, where it forms a zone between the zones of $A$. muldoonense and A. amphibolum (Cobban, 1987, p. 24). Associated ammonites at the Wyoming localities include Paraconlinoceras leonense (Adkins), a species now known from the Mancos Shale of west-central New Mexico.

Vascoceras birchbyi Cobban and Scott (1972) was described from the Bridge Creek Member of the Greenhorn Limestone of the Pueblo area of Colorado, and assigned to the Watinoceras coloradoense Zone. On some charts of the 1970s, both species were listed together as an early Turonian zone indice, but later V. birchbyi was applied alone because it was more widely distributed, as in the following table from Cobban and Hook (1983). 


\begin{tabular}{|c|c|c|c|}
\hline \multicolumn{2}{|c|}{ Stage } & Zone & Subzone \\
\hline \multirow{14}{*}{\begin{tabular}{l} 
등 \\
\hdashline$\frac{1}{c}$ \\
$\stackrel{ }{ }$ \\
$\vdash$
\end{tabular}} & \multirow{6}{*}{ upper } & Prionocyclus quadratus & \\
\hline & & Prionocyclus novimexiconus & \\
\hline & & \multirow{2}{*}{ Prionocyclus wyomingensis } & Scophites ferronensis \\
\hline & & & Scophites worreni \\
\hline & & \multirow{2}{*}{ Prionocyclus mocombi } & Coilopoceros inflatum \\
\hline & & & Coilopoceros colleti \\
\hline & \multirow{5}{*}{ middle } & \multirow{2}{*}{ Prionocyclus hyotti } & Coilopoceros springeri \\
\hline & & & Hoplitoides sondovolensis \\
\hline & & Subprionocyclus percarinatus & \\
\hline & & & Collignoniceros woollgari regulare \\
\hline & & & Collignoniceros woollgori woollgari \\
\hline & \multirow{3}{*}{ lower } & Mommites nodosoides & \\
\hline & & Voscoceros birchbyi & \\
\hline & & Pseudospidoceros flexuosum & \\
\hline \multirow{9}{*}{ 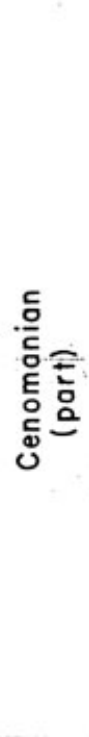 } & \multirow{5}{*}{ upper } & Neocordioceros juddii & \\
\hline & & Voscoceras gamai & \\
\hline & & Sciponoceras gracile & \\
\hline & & Metoicocieros mosbyense & \\
\hline & & Calycoceras conitourinum & \\
\hline & \multirow{4}{*}{ middle } & \multirow{3}{*}{ Aconthoceros omphibolum } & Plesiaconthoceros wyomingense \\
\hline & & & Acanthoceros amphibolum amphibolum \\
\hline & & & Acanthoceros amphibolum alvaradoense \\
\hline & & Conlinoceros torrontense & \\
\hline
\end{tabular}

Figure 9. Cenomanian-Turonian ammonite sequence in the Western Interior (Cobban and Hook, 1983, table 1). In the above figure, the ammonite Pseudaspidoceras flexuosum 
Powell (1963), described from Trans-Pecos Texas, was added at the base of the Turonian just below V. birchbyi, and the poorly defined ammonite Subprionocyclus percarinatus (Hall and Meek) was replaced by the much better defined Collignonoceras praecox (Haas, 1946; Kennedy et al., 2001). The table also shows the application of the ammonite Subfamily Collignoniceratinae for the Turonian in the southern part of the Western Interior with Prionocyclus quadratus at the top of the Turonian. That species, described from the Sage Breaks Member of the Carlile Shale of the Black Hills area (Cobban, 1953), has appeared on numerous tables from 1979-1994, when it was replaced by $P$. germari.

The upper Cenomanian Sciponoceras gracile Zone was divided into a lower subzone of Vascoceras diartianum (d'Orbigny) and an upper subzone of Euomphaloceras septemseriatum (Cragin) (Cobban, 1988b, fig. 2), and these were treated later as regular zones (Obradovich, 1994; Cobban and Larson, 1997), when S. gracile was found to range through the zones of $V$. diartianum-Neocardioceras juddii (Cobban et al., 1989).

Extensive field work by Hook and Cobban in southwestern New Mexico revealed a zone of the ammonite Burroceras clydense Cobban, Hook and Kennedy, between the zones of Sciponoceras gracile [Euomphaloceras septemseriatum] and Neocardioceras juddii (Cobban et al., 1989), and since then clydense has appeared in the zonal schemes (Kennedy and Cobban, 1991a, fig. 2; Obradovich, 1994, fig. 2), and has replaced Vascoceras cauvini of earlier reports as noted by Cobban (1990, fig. 2). 
The ammonite genus Forresteria Reeside (1932), named for the deceased Robert Forrester, Salt Lake City, Utah, can be used for zoning the upper part of the Turonian and the lower Coniacian in Colorado, Utah, and New Mexico, where scaphitid ammonites of that age are scarce in contrast to their abundance farther north. Forresteria in the Western Interior was treated by Kennedy and Cobban (1991b). The sequence of species related to the inoceramid zonation seems to be as follows, although the total range of each Forresteria species is unknown at present:

\begin{tabular}{|c|c|c|}
\hline Stage & Forresteria & Inoceramid species \\
\hline $\begin{array}{l}\text { Lower } \\
\text { Coniacian }\end{array}$ & $\begin{array}{l}\text { alluaudi } \\
\text { brancoi and hobsoni }\end{array}$ & $\begin{array}{l}\text { Cremnoceramus crassus crassus } \\
\text { C. crassus inconstans } \\
\text { C. deformis dobrogensis } \\
\text { C. deformis erectus }\end{array}$ \\
\hline $\begin{array}{l}\text { Upper } \\
\text { Turonian (part) }\end{array}$ & peruana & $\begin{array}{l}\text { C. waltersdorfensis } \\
\text { Mytiloides scupini }\end{array}$ \\
\hline
\end{tabular}

Figure 10. Occurance of species of Forresteria in the Western Interior and the inoceramid zone in which they have been found.

A few tables have Forresteria as zones in the Western Interior (Cobban and Hook, 1989; Obradovich, 1994; Hancock et al., 1994). 


\section{Some Stage Boundaries}

The Cenomanian-Turonian boundary in the Western Interior has an interesting history. Reeside (1944) used the ammonite Metoicoceras whitei as the lowest zone of the Turonian, and listed the bivalve Gryphaea newberryi among the underlying Cenomanian fossils. Metoicoceras whitei Hyatt (1903) is now considered a synonym of $M$. geslinianum (d’Orbigny, 1841), and G. newberryi is now assigned to the genus Pycnodonte and occurs with M. geslinianum. The straight ammonite Sciponoceras gracile (Shumard) was included with $M$. whitei in the basal zone of the Turonian by Cobban (1951a,b, fig. 2), but in their GSA paper(1952), Cobban and Reeside showed only S. gracile as a zonal fossil. From 1952 to 1972, the S. gracile Zone was shown in many publications as the basal zone of the Turonian. But in 1972, Cobban and Scott placed it at the top of the Cenomanian, and designated Watinoceras coloradoense (Henderson) as the basal Turonian zone. As noted earlier, Pseudaspidoceras flexuosum was recognized as the basal Turonian zone from 1983-1991, when $W$. devonense Wright and Kennedy (1981), a species described from the base of the Turonian of England, was recorded from just below the $P$. flexuosum Zone in the Pueblo area, Colorado (Kennedy and Cobban, 1991a,b, fig. 2; see also Kennedy et al., 2000, fig. 6; 2005, fig. 8).

The Turonian Stage was not subdivided in the Western Interior until 1978, when Kauffman et al. recognized lower, middle, and upper substages. The boundary between the middle and upper substages was placed at the contact between the zone of Inoceramus howelli-Prionocyclus hyatti below and the zone of Inoceramus dimidius- 
Prionocyclus macombi above. The boundary between the middle and upper Turonian remained stable from 1978-2000 until Walaszczyk, while studying Western Interior inoceramids at the Denver Federal Center, found that the European I. costellatus Woods (1912) of authors, widely used as a guide to the base of the upper Turonian, was the same species as I. perplexus Whitfield (1877) of the Western Interior zone of Scaphites whitfieldi. Walaszczyk and Cobban (2000), accordingly, considered the S. whitfieldi-I. perplexus Zone as the base of the upper Turonian and lowered the I. dimidius-P. macombi Zone (including the zone of Scaphites ferronensis and S. warreni) to the upper part of the middle Turonian.

The Campanian-Maastrichtian boundary has also been a problem. In their 1952 GSA paper, Cobban and Reeside placed the boundary at the base of the Baculites baculus Zone following the judgment of George Jeletzky of the Geological Survey of Canada (in Cobban and Reeside, 1952, p. 1026-27). The Maastrichtian zonation proposed, from the oldest to the youngest was as follows: Baculites baculus, B. grandis, and then a gap followed by Discoscaphites nicolletii, and D. nebrascensis. The lower part of the gap was filled by Sphenodiscus (Coahuilites)-Discoscaphites n. sp. (Gill and Cobban, 1966, table 2), who assigned the D. nicolletii of the earlier reports to Hoploscaphites nicolletii. The use of Sphenodiscus (Coahuilites) disappeared in the late 1980s, and the Discoscaphites n. sp. became Hoploscaphites aff. nicolletii (Cobban et al., 1992, fig. 1; Obradovich, 1994, fig. 2). The latter species was described by Landman and Waage (1993) as $H$. birkelundi (spelling corrected to birkelundae by Landman and Cobban, 2003), and the species name has appeared on numerous tables since 1997, as in the following table: 


\begin{tabular}{|c|c|c|c|}
\hline 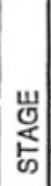 & 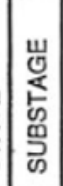 & 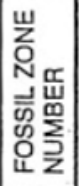 & FOSSIL ZONE \\
\hline 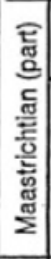 & 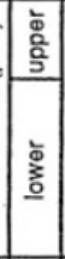 & $\begin{array}{l}1 \\
2 \\
3 \\
4 \\
5 \\
6 \\
7\end{array}$ & $\begin{array}{l}\text { Jeletzkytes nebrascensis } \\
\text { Hoploscaphites nicolleti } \\
\text { Hoploscaphites birkelundi } \\
\text { Baculites clinolobatus } \\
\text { Baculites grandis } \\
\text { Baculites baculus } \\
\text { Baculites eliasi }\end{array}$ \\
\hline 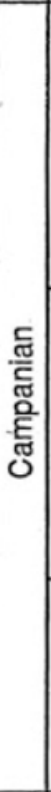 & 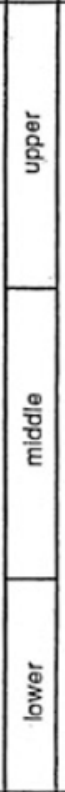 & $\begin{array}{r}8 \\
9 \\
10 \\
11 \\
12 \\
13 \\
14 \\
15 \\
16 \\
17 \\
18 \\
19 \\
20 \\
21 \\
22 \\
23 \\
24 \\
25 \\
26 \\
27 \\
28 \\
29\end{array}$ & $\begin{array}{l}\text { Baculites jenseni } \\
\text { Baculites reesidei } \\
\text { Baculites cuneatus } \\
\text { Baculites compressus } \\
\text { Didymoceras cheyennense } \\
\text { Exiteloceras jenneyi } \\
\text { Didymoceras stevensoni } \\
\text { Didymoceras nebrascense } \\
\text { Baculites scotti } \\
\text { Baculites reduncus } \\
\text { Baculites gregoryensis } \\
\text { Baculites perplexus } \\
\text { Baculites sp. (smooth) } \\
\text { Baculites asperiformis } \\
\text { Baculites maclearni } \\
\text { Baculites obtusus } \\
\text { Baculites sp. (weak flank ribs) } \\
\text { Baculites sp. (smooth) } \\
\text { Scaphites hippocrepis III } \\
\text { Scaphites hippocrepis II } \\
\text { Scaphites hippocrepis I } \\
\text { Scaphites leei III }\end{array}$ \\
\hline 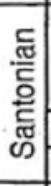 & \begin{tabular}{|c|} 
음 \\
mid \\
low \\
\end{tabular} & $\begin{array}{l}30 \\
31 \\
32 \\
33 \\
34 \\
\end{array}$ & $\begin{array}{l}\text { Desmoscaphites bassleri } \\
\text { Desmoscaphites erdmanni } \\
\text { Clioscaphites choteauensis } \\
\text { Clioscaphites vermiformis } \\
\text { Clioscaphites saxitonianus }\end{array}$ \\
\hline 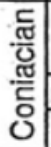 & \begin{tabular}{|l|} 
¿ू. \\
$\frac{2}{3}$ \\
mid \\
low \\
\end{tabular} & $\begin{array}{l}35 \\
36 \\
37 \\
38\end{array}$ & $\begin{array}{l}\text { Scaphites depressus } \\
\text { Scaphites ventricosus } \\
\text { Cremnoceramus deformis } \\
\text { Forresteria peruana }\end{array}$ \\
\hline
\end{tabular}

Figure 11. Coniacian-Maastrichtian ammonite sequence in the Western Interior in which the zones were numbered 1-38 (Merewether et al., 1997, part of figure 4)

The Campanian Maastrichtian boundary in the above table was placed at the base of the Baculites eliasi Zone following a recommendation by Kennedy and Cobban (1993, fig. 4), but it was raised again to the base of the baculus Zone as a result of an 
investigation of Western Interior inoceramid bivalves (Walaszczyk et al., 2001).

However, in regard to the sequence at Tercis, France, which has the Global Standard Stratotype Section and Point for the Campanian-Maastrichtian Stage boundary, the base of the Maastrichtian should be placed high in the Baculites eliasi Zone (Walaszczyk et al., 2002). The latter placement of the boundary is accepted for the present table, although strontium isotope stratigraphy would have it a little lower within the Baculites jenseni Zone (McAuthor et al., 1992).

\section{Inoceramid Zonation}

Although a few inoceramid species were included in earlier reports (Stephenson and Reeside, 1938; Cobban and Reeside, 1952), including a late Turonian-Coniacian sequence (Merewether et al., 1975, table 1), the first detailed zonation of Western Interior Late Cretaceous inoceramids was by Kauffman et al. (1978) in which the inoceramids were treated by E.G. Kauffman, the ammonites by Cobban, and the Foraminifera by D.L. Eicher. Their zonal sequence was summarized in the following figure: 


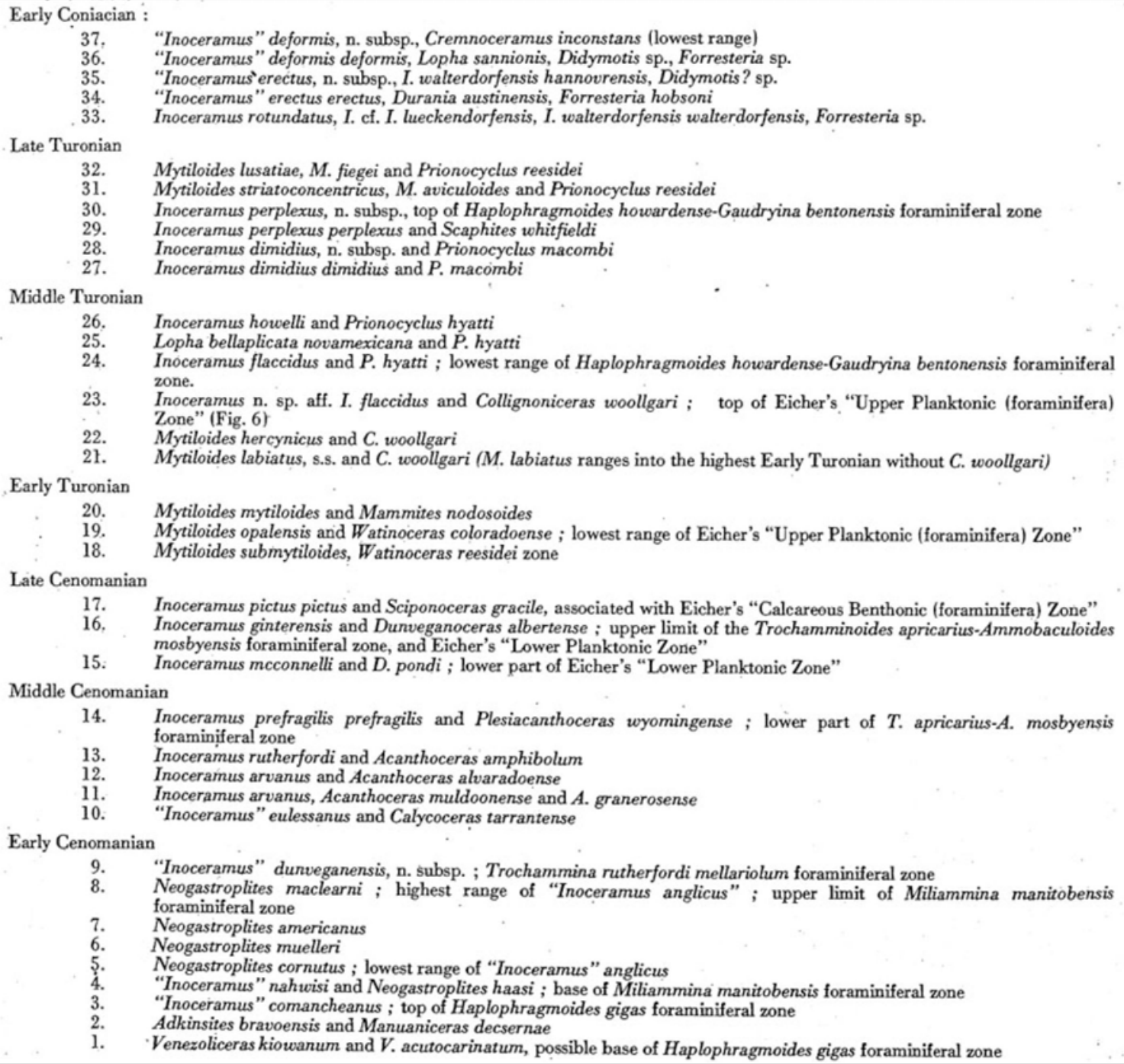

14. Inoceramus prefragilis prefragilis and Plesiacanthoceras wyomingense; lower part of $T$. apricarius-A. mosbyensis

Figure 12. Early Cenomanian-early Coniacian integrated zonation of ammonites, inoceramids, and foraminifera (Kauffman et al., 1978, xxiii-16). 
A zonation for the middle Cenomanian-lower Coniacian that has an inoceramid species for each ammonite was presented in the following paper on south-central New Mexico modified from Cobban (1986):

\begin{tabular}{|c|c|c|}
\hline \multicolumn{2}{|c|}{ STAGE } & ZONE \\
\hline \multirow{2}{*}{ 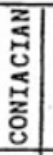 } & \multirow{2}{*}{ 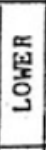 } & Forresteria, Inoceramus deformis \\
\hline & & Forresteria, Inoceramus erectus \\
\hline \multirow{6}{*}{ 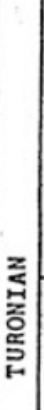 } & \multirow{4}{*}{ 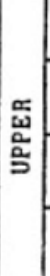 } & Prionocyclus quadratus, Mytiloides incertus \\
\hline & & Scaphites whitfieldi, Inoceramus perplexus \\
\hline & & Prionocyclus wyomingensis, Inoceramus dinidius \\
\hline & & Prionocyclus macombi, Inoceramus dimidius \\
\hline & \multirow{2}{*}{$\begin{array}{l}\text { 뎍 } \\
\text { 음 } \\
\text { 볼 }\end{array}$} & Prionocyclus hyatti, Inoceranus howelli \\
\hline & & Collignoniceras woollgari, Mytiloides hercynicus \\
\hline & \multirow{3}{*}{$\begin{array}{l}\text { 䱌 } \\
\text { 吕 }\end{array}$} & Mammites nodosoides, Mytiloides mytiloides \\
\hline & & -Vascoceras birchbyi, Mytiloides plicatus \\
\hline & & Pseudaspidoceras flexuosun, Mytiloides plicatus \\
\hline \multirow{8}{*}{ 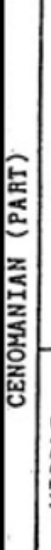 } & \multirow{5}{*}{ 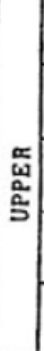 } & Neocardioceras juddii, Inoceramus heinzi \\
\hline & & Vascoceras cauvini, Inoceramus heinzi \\
\hline & & Sciponoceras gracile, Inoceramus pictus \\
\hline & & Metoicoceras mosbyense, Inoceramus ginterensis \\
\hline & & Calycoceras canitaurinum, Inoceramus prefragilis \\
\hline & \multirow{3}{*}{$\begin{array}{l} \\
\text { 녁 } \\
\text { 음 } \\
\text { 봉 }\end{array}$} & Plesiacanthoceras wyomingense cobbani, Inoceramus prefragilis \\
\hline & & Acanthoceras amphibolum, Inoceranus arvanus \\
\hline & & Conlinoceras tarrantense, Inoceramus eulessanus \\
\hline
\end{tabular}

Figure 13. Integrated ammonite and inoceramid zonation for the middle Cenomanian into the lower Coniacian of New Mexico (Cobban, 1986, modified from fig. 2). 
The Western Interior inoceramids were thoroughly investigated by Walaszczyk during parts of 1998-1999, while he was in Denver on a Fulbright Foundation research fellowship. The inoceramid zonation (upper Cenomanian-Maastrichtian) in the present table is based on his work (Walaszczyk and Cobban, 2000; Walaszczyk et al., 2001; Walaszczyk and Cobban, in Kennedy et al., 2000; Walaszczyk and Cobban, 2006a,b, in press). Minor changes include an undescribed species referred to as Inoceramus aff. dimidius in the older part of the I. dimidius Zone of earlier reports. At the base of the middle Cenomanian, I. macconnelli Warren 1930a is used in place of the synonym $I$. eulessanus Stephenson 1953 of earlier tables. 


\section{Origin of Generic Names of Ammonites}

Most of the generic names of ammonites end in ceras_(Greek, keras, horn) or ites (Greek, ites, stone)

Acanthoceras. Greek, akanthos, prickly; for its shell with several rows of nodes.

Neumayr, 1875.

Baculites. Latin, baculum, rod or staff; for its straight shell. Lamarck, 1799.

Burroceras. For Big Burro Mountains, Grant County, New Mexico. Cobban, et al., 1989.

Clioscaphites. Greek, kleio, close; for the tightly enrolled shell. Cobban, 1952.

Collignoniceras. For the French Général Maurice Collignon, who authored many papers on ammonites, especially those from Madagascar. Breistroffer, 1947.

Conlinoceras. For James P. Conlin (1908-1972), Fort Worth, Texas, who collected and carefully documented numerous Cretaceous fossils, and donated them to the USGS. Cobban and Scott, 1972.

Desmoscaphites. A scaphitid ammonite that has the early whorls with constrictions resembling the constrictions in the ammonite Desmoceras. Reeside, 1927b.

Didymoceras. Greek, didymos, double, for the two growth forms. Hyatt, 1894.

Dunveganoceras. For the Dunvegan Formation, Alberta, Canada. Warren and Stelck, 1940.

Euomphaloceras. Greek, eu, true; omphalor, navel; probably from the navel-like umbilicus of the ammonite. Spath, 1923.

Exiteloceras. Greek, exitglos, becoming extinct. Hyatt, 1894. 
Hoploscaphites. Greek, hoplo, shield; for the shield-like appearance of laterally compressed scaphitid ammonites. Nowak, 1911.

Jeletzkyites. For Jurij Alexandrovich Jeletzky, (1915-1988), paleontologist with the Geological Survey of Canada from 1948-1988. Riccardi, 1983.

Mammites. Latin, mamma, breast, teat; for the ornament of nipple-like nodes. Laube and Brüder, 1887.

Neocardioceras. Greek, neos, young; for a Cretaceous ammonite younger than the somewhat similar Jurassic ammonite Cardioceras. Spath, 1926.

Nigericeras. For Niger, Africa. Schneegans, 1943.

Plesiacanthoceras. Greek, plesios, near; for its resemblance to the ammonite Acanthoceras. Haas, 1964.

Prionocyclus. Greek, priono, saw; kyklios, circular; for resemblance to a circular saw. Meek, 1871.

Pseudaspidoceras. Greek, pseudes, false; for resemblance to the ammonite Aspidoceras, but not that genus. Hyatt, 1903.

Scaphites. Latin, scapha, light boat; for its resemblance to a boat that has both ends curved. Parkinson, 1811.

Vascoceras. Latin, vas, vessel; for resemblance to a vessel. Choffat, 1899.

Watinoceras, For Watino, Alberta, Canada. Warren, 1930a. 


\section{Origin of Species Names of Ammonites}

Origin of the names is followed by the author's name and date (see References)

albertense. For Alberta, Canada. Warren, 1930b.

amphibolum. Greek, amphibolus, doubtful; for the assignment doubtfully to

Acanthoceras. Morrow, 1935.

asperiformis. Latin, asper, rough, forma, shape; for its ornament. Meek, 1876a.

baculus. Latin, baculum, rod or staff. Meek and Hayden, 1861; Meek, 1876a.

bassleri. For Harvey Bassler (1883-1950), paleontologist, who collected the type

specimen. Reeside, 1927b.

bellense. For Bell County, Texas. Adkins, 1928.

birchbyi. For the late William H. Birchby, Pueblo, Colorado, who did bed-by-bed collecting from the Greenhorn Limestone in the Pueblo area, and then donated his fossils to the USGS. Cobban and Scott, 1972.

birkelundae. For Tove Birkelund (1939-1986), Copenhagen, Denmark, paleontologist who wrote many papers on Cretaceous cephalopods including a monograph on ammonites from Greenland. Landman and Waage, 1993.

cheyennense. For Cheyenne River in west-central South Dakota. Meek and Hayden, 1856.

choteauensis. For Choteau, Montana, where the holotype was found nearby. Cobban, 1952 
clinolobatus. Latin, clino, slant or inclined, lobus, lobe; for the lateral lobe of the suture slanted at an angle to the axis of the shell. Elias, 1933.

clydense. For Clyde Canyon in the Big Burro Mountains, Grant County, New Mexico. Cobban, et al. (1989).

compressus. French, compresse, compress, for its compressed cross-section. Say, 1820. conditum. Latin, conditus, hidden, for the paratype specimen that was hidden in the back of a drawer in the Department of Geology, University of Wyoming. Haas, 1951. cuneatus. Latin, wedge-shaped; for the cross-section of the shell. Cobban, 1962b. depressus. Latin, pressed down; for the depressed cross-section of the shell. Reeside, 1927c.

devonense. For the Devon coast, south-west, England. Wright and Kennedy, 1981. diartianum. Name given to a Turonian ammonite, probably from France. d’Orbigny, 1850.

eliasi. For Maxim Kondradovich Elias (1889-1982), for his excellent stratigraphic and paleontologic investigations of the Pierre Shale of western Kansas. Cobban, 1958b.

erdmanni. For Charles Edgar Erdmann (1897-1971), USGS geologist, he and his assistants made over 500 carefully located geographically and stratigraphically collections of fossils from the Sweetgrass Arch and Disturbed Belt of northwestern Montana. Cobban, 1952.

ferronensis. For the Ferron Sandstone Member of the Mancos Shale of central Utah. Cobban, 1952.

flexuosum. Latin, flexuosus, bending; for the fossil's flexuous ribbing. Powell, 1963. 
germari. For Professor Ernst Friederich Germar (1786-1853), mineralogist and entomologist and director of the Mineralogical Museum at Halle, Germany. Reuss, 1845.

grandis. Latin, large; for the large size of species. Hall and Meek, 1856.

granerosense. For the Graneros Shale that provided the type. Cobban and Scott, 1972.

gregoryensis. For the Gregory Member of the Pierre Shale, Lyman County, South

Dakota. Cobban, 1951b.

hippocrepis. Greek, hippo, horse; krepis, shoe; for the horseshoe-shaped cross-section. DeKay, 1828.

hyatti. For Alpheus Hyatt (1838-1901), eminent American paleontologist. Stanton, 1894.

jenneyi. For Walter Proctor Jenney (1849-1921), geologist-in-charge of an exploring expedition of the Black Hills in 1875. Whitfield, 1877.

jenseni. For the late Fred Scott Jensen, USGS geologist in the early 1960s who collected the type specimens. Cobban, 1962b.

juddii. For the English geologist “M. le professeur Judd.” Barrois and de Guerne, 1878.

leei. For Willis Thomas Lee (1864-1926), USGS geologist, who collected the type specimen. Reeside, 1927b.

maclearni. For Frank Harris McLearn (1885-1964). prominent paleontologist of the Geological Survey of Canada. Landes, 1940.

macombi. For Captain John N. Macomb (1810-1889), in command of the U.S.

Topographical Engineers San Juan exploring expedition in New Mexico in 1859. Meek, 1876b. 
mariasensis. For Marias River in north-central Montana, where the holotype was collected from the river bank. Cobban, 1952.

muldoonense. For Muldoon Hill in Pueblo County, Colorado, about 30 kilometers southwest of Pueblo and site of "Muldoon Man" carved out of gypsum and then buried to be "discovered" later by the perpetrator for a money-making display. Cobban and Scott, 1972.

nebrascensis. For Nebraska Territory. Owen, 1852.

nicolletii. For Joseph Nicolas Nicollet (1786-1843), French immigrant scientist, who explored and mapped the upper Mississippi River Valley and collected Cretaceous fossils in South Dakota in 1839. Morton, 1842.

nigricollensis. Latin, nigra, black; collis, hill, for the Black Hills of South Dakota. Cobban, 1952.

nodosoides. Latin, nodosus, full of knots; for the nodate ornament. Schlüter, 1871. obtusus. Latin, blunt; for the ornament of node-like arcuate ribs or blunt nodes. Meek, 1876a.

perplexus. Latin, puzzling; for the difficulty in separating the species from other early Campanian species. Cobban, 1962a.

pondi, For. W.F. Pond, Greybull, Wyoming, who assisted Otto Haas in the field. Haas, 1949.

praecox. Latin, prae, before; for the accelerated development of its ornament in contrast to other related species. Haas, 1946.

preventricosus. Latin, prae, before; for occurence before (below) the species ventricosus. Cobban, 1952. 
problematicum. Greek, problema, problem or puzzle; for taxonomic status of the ammonite Dunveganoceras problematicum. Cobban, 1988a.

reduncus. Latin, curved; for the curved form. Cobban, 1977.

reesidei. For John Bernard Reeside, Jr. (1889-1958), eminent USGS paleontologist. Elias, 1933.

saxitonianus. For Saxitonia “the Rocky Mountain country.” McLearn, 1929.

scotti. For Glenn R. Scott, retired USGS geologist, who added much to our knowledge of the Cretaceous rocks and fossils of the Western Interior. Cobban, 1958b; 1972). septemseriatum. Latin, septum, partition; seria, pot; for its resemblance to a chambered pot. Cragin, 1893.

stevensoni. For Professor John James Stevenson (1841-1924), who "has done so much good work among Cretaceous rocks of the West.” Whitfield, 1877.

tarrantense. For Tarrant County, Texas. Adkins, 1928.

ventricosus. Latin, ventricose swelling; for the inflated form. Meek and Hayden, 1862. vermiformis. Latin, vermiculatus, worm-like; probably from its fanciful resemblance to a coiled caterpillar. Meek and Hayden, 1862.

warreni. For Lieutenant Gouverneur Kemble Warren (1830-1882), Corps of

Topographical Engineers, who led a geographical and geological survey of the Black Hills in 1857. Meek and Hayden, 1860.

whitfieldi. For Robert Parr Whitfield (1828-1910), long-time curator of geology and invertebrate paleontology at the American Museum of Natural History, who described many Cretaceous fossils. Cobban, 1952.

woollgari. For Thomas Woollgar, “esteemed friend” of Gideon Mantell, 1822. 
wyomingense. For the State of Wyoming. Reagan,1924. 


\section{REFERENCES}

Adkins, W. S., 1928, Handbook of Texas Cretaceous fossils: Texas University Bulletin, 2838, 385 p.

Baadsgaard, H., Lerbekmo, J.F., and Wijbrans, J.R., 1993, Multimethod radiometric age for a bentonite near the top of the Baculites reesidei Zone of southwestern Saskatchewan (Campanian-Maastrichtian stage boundary?). Canadian Journal of Earth Sciences, v. 30, p. 769-775.

Barrois, C. and de Guerne, J., 1878, Description de quelques espèces nouvelles de la Craie de l’est du Bassin de Paris: Société Géologique du Nord Annales, 5, 42-64.

Breistroffer, M., 1947, Notes de nomenclature paléozoologique: Procès-Verbaux Mensuels Société Scientifique du Dauphiné, 26 ${ }^{\text {th }}$ year, no. 195, 5 p. (unnumbered).

Choffat, P., 1899, Les Ammonées du Bellasien, des couches à Neolobites vibrayeanus, du Turonien et du Sénonien, 2d ser., Recueil d’études paléontologiques sur la faune crétacique du Portugal, v. 1, Espèces nouvelles ou peu connues: Section des Travaux Géologiques du Portugal, 41-86, [1898 imprint].

Cobban, W. A., 1951a, Colorado shale of central and northwestern Montana and equivalent rocks of Black Hills: American Association of Petroleum Geologists Bulletin, 35 (10), 2170-2198.

Cobban, W. A., 1951b, New species of Baculites from the Upper Cretaceous of Montana and South Dakota: Journal of Paleontology, 25 (6), 817-821.

Cobban, W. A., 1952, Scaphitoid cephalopods of the Colorado Group: U.S. Geological Survey Professional Paper, 239, 42 p. (1951 imprint).

Cobban, W. A., 1953, A new species of Prionocyclus from Upper Cretaceous Carlile Shale: Journal of Paleontology, 27 (3), 353-355.

Cobban, W. A, 1958a, Late Cretaceous fossil zones of the Powder River Basin, Wyoming and Montana: Wyoming Geological Association Guidebook $13^{\text {th }}$ Annual Field Conference, Powder River Basin, 114-119.

Cobban, W. A., 1958b, Two new species of Baculites from the Western Interior region: Journal of Paleontology, 32 (4), 660-665.

Cobban, W. A., 1961, The ammonite family Binneyitidae Reeside in the Western Interior of the United States: Journal of Paleontology, 35 (4), 737-758. 
Cobban, W. A., 1962a, Baculites from the lower part of the Pierre Shale and equivalent rocks in the Western Interior: Journal of Paleontology, 36 (4), 704-718.

Cobban, W. A., 1962b, New Baculites from the Bearpaw Shale and equivalent rocks of the Western Interior: Journal of Paleontology, 36 (1), 126-135.

Cobban, W. A., 1969, The Late Cretaceous ammonites Scaphites leei Reeside and Scaphites hippocrepis (DeKay) in the western interior of the United States: U.S. Geological Survey Professional Paper, 619, 29 p.

Cobban, W. A., 1972, New and little-known ammonites from the Upper Cretaceous (Cenomanian and Turonian) of the western interior of the United States: U.S. Geological Survey Professional Paper, 699, 24 p. [1971 imprint].

Cobban, W. A., 1977, A new curved baculite from the Upper Cretaceous of Wyoming: U.S. Geological Survey Journal of Research, 5 (4), 457-462.

Cobban, W. A., 1984, Mid-Cretaceous ammonite zones, Western Interior, United States: Bulletin of the Geological Society of Denmark, 33 (1-2), 71-89.

Cobban, W. A., 1986, Upper Cretaceous molluscan record from Lincoln County, New Mexico: Southwest Section of AAPG, Transactions and Guidebook of 1986 Convention, Ruidoso, New Mexico, 77-89.

Cobban, W. A., 1987, Some middle Cenomanian (Upper Cretaceous) acanthoceratid ammonites from the Western Interior of the United States: U.S. Geological Survey Professional Paper, 1445, 28 p.

Cobban, W. A., 1988a, Some acanthoceratid ammonites from upper Cenomanian (Upper Cretaceous) rocks of Wyoming: U.S. Geological Survey Professional Paper, 1353, $17 \mathrm{p}$.

Cobban, W. A., 1988b, Tarrantocaras Stephenson and related ammonoid genera from Cenomanian (Upper Cretaceoous) rocks in Texas and the Western Interior of the United States: U.S. Geological Survey Professional Paper, 1473, 30 p.

Cobban, W. A., 1990, Ammonites and some characteristic bivalves from the Upper Cretaceous Frontier Formation, Natrona County, Wyoming: U.S. Geological Survey Bulletin, 1917B, 13 p.

Cobban, W. A. and Hook, S.C., 1979, Collignnoniceras woollgari woollgari (Mantell) ammonite fauna from Upper Cretaceous of Western Interior, United States: New Mexico Bureau of Mines and Mineral Resources Memoir 37, 51p. 
Cobban, W. A. and Hook, S.C., 1983, Mid-Cretaceous (Turonian) ammonite fauna from Fence Lake area of west-central New Mexico: New Mexico Bureau of Mines and Mineral Resources Memoir, 41, 50p.

Cobban, W. A., Hook, S. C. and Kennedy, W. J., 1989, Upper Cretaceous rocks and ammonite faunas of southwestern New Mexico: New Mexico Bureau of Mines and Mineral Resources Memoir, 45, 137 p.

Cobban, W. A. and Larson, N. L., 1997, Marine Upper Cretaceous rocks and their ammonite record along the northern flank of the Black Hills uplift, Montana, Wyoming, and South Dakota: University of Wyoming Contributions to Geology, $32(1), 27-35$.

Cobban, W. A.and Reeside, J. B., Jr., 1952, Correlation of the Cretaceous formations of the Western Interior of the United States: Geological Society of America Bulletin, 63 (10), 1011-1043.

Cobban, W. A. and Scott, G. R., 1972, Stratigraphy and ammonite fauna of the Graneros Shale and Greenhorn Limestone near Pueblo, Colorado: U.S. Geological Survey Professional Paper, 645, 108 p.

Cobban, W. A., Kennedy, W. J. and Scott, G. R., 1992, Upper Cretaceous heteromorph ammonites from the Baculites compressus zone of the Pierre Shale in northcentral Colorado: U.S. Geological Survey Bulletin, 2024-A, A1-A11.

Cooper, M. R., 1994, Towards a phylogenetic classification of the Cretaceous ammonites III, Scaphitaceae: Neues Jahrbuch für Geologie und Paläontologie, Abhandlungen, 193 (2), 165-193.

Cooper, M. R., 1998, Towards a phylogenetic classification of the Cretaceous ammonites. VI, Mammitinae: Neues Jahrbuch für Geologie und Paläontologie, Abhandlungen, 209 (2), 217-230.

Cragin, F. W., 1893, A contribution to the invertebrate paleontology of the Texas Cretaceous: Texas Geological Survey $4^{\text {th }}$ Annual Report, 2, 139-246.

DeKay, J. E., 1828, Report on several multilocular shells from the State of Delaware; with observations of a second specimen of the new fossil genus Eurypterus: Lyceum of Natural History of New York, Annals, 2, 273-279 [1827 imprint].

Eldridge, G. H., 1888, On some stratigraphical and structural features of the country around Denver, Colorado: Colorado Scientific Society Proceedings, 3, 86-118.

Eldridge, G. H., 1889, Some suggestions upon the methods of groupings the formations of the Middle Cretaceous and the employment of an additional term in its nomenclature: American Journal of Science, 38, 313-321. 
Elias, M. K., 1933, Cephalopods of the Pierre formation of Wallace County, Kansas, and adjacent area: University of Kansas Science Bulletin, 21 (9), 289-363.

Gale, A.S., 1989, A Milankovitch scale for Cenomanian time: Terra Research, v. 1, no.5, 420-425.

Gill, J. R. and Cobban, W. A., 1965, Stratigraphy of the Pierre Shale, Valley City and Pembina Mountain areas, North Dakota: U. S. Geological Survey Professional Paper, 392A, 20p.

Gill, J. R. and Cobban, W. A., 1973, Stratigraphy and geologic history of the Montana Group and equivalent rocks, Montana, Wyoming, and North and South Dakota: U. S. Geological Survey Professional Paper, 776, 37 p.

Gill, J. R. and Cobban, W. A., 1966, The Red Bird section of the Upper Cretaceous Pierre Shale in Wyoming, with a section on A new echinoid from the Cretaceous Pierre Shale of eastern Wyoming, by P.M. Kier: U.S. Geological Survey Professional Paper, 393-A, 73p.

Gill, J. R., Merewether, E. A. and Cobban, W. A., 1970, Stratigraphy and nomenclature of some Upper Cretaceous and lower Tertiary rocks in south-central Wyoming: U.S. Geological Survey Professional Paper, 667, 50 p.

Gradstein, F.M. and Ogg, J. G, 2004, Geologic time scale 2004—why, how, and where next: Lethaia, 37, 175-181.

Haas, O., 1946, Intraspecific variation in, and ontogeny of, Prionotropis woollgari and Prionocyclus wyomingensis: American Museum of Natural History Bulletin, 86, 141-224.

Haas, O., 1949, Acanthoceratid Ammonoidea from near Greybull, Wyoming: American Museum of Natural History Bulletin, 93, 39 p.

Haas, O., 1951, Supplementary notes on the ammonite genus Dunveganoceras: American Museum Novitates, 1490, 21 p.

Haas, O., 1964, Plesiacanthoceras, new name for Paracanthoceras Haas, 1963, non Furon, 1935: Journal of Paleontology, 38 (3), 610.

Hall, J. and Meek, F. B., 1856, Descriptions of new species of fossils from the Cretaceous formations of Nebraska, with observations upon Baculites ovatus and $B$. compressus, and the progressive development of the septa in Baculites, Ammonites, and Scaphites: American Academy of Arts and Science Memoir, new ser., 5, 379-411. 
Hancock, J. M., Kennedy, W. J. and Cobban, W. A., 1994, A correlation of the upper Albian to basal Coniacian sequences of northwest Europe, Texas and the United States Western Interior, in Caldwell, W. G. E., and Kauffman, E. G., eds., Evolution of the Western Interior basin: Geological Association of Canada Special Paper, 39, 453-476 [1993 imprint].

Heinze, R., 1930, Zur stratigraphischen Stellung der Sonnenbergschichten bei Waltersdorf i. Sa. (westsüdwestlich von Zittau). Beiträge zur Kenntnis der oberkretazischen Inoceramen IX. Jahresbericht des Niedersächsischen Geologischen Vereins zu Hannover, 23, 25-29.

Henderson, J. 1908, New species of Cretaceous invertebrates from northern Colorado: U.S. National Museum Proceedings, v. 34, no. 1611, p. 259-264.

Hicks, J. F., Johnson, K. R., Obradovich, J. D., Tauxe, L. and Clark, D., 2002, Magnetostratigraphy and geochronology of the Hell Creek and basal Fort Union Formations of southwestern North Dakota and a recalibration of the age of the Cretaceous-Tertiary boundary, in Hartman, J. H., Johnson, K. R., and Nichols, D. J., eds., The Hell Creek Formation and the Cretaceous-Tertiary boundary in the northern Great Plains: Geological Society of America Special Paper, 361, 35-55.

Hook, S. C. and Cobban, W. A., 1981, Late Greenhorn (mid-Cretaceous) discontinuity surfaces, southwest New Mexico: New Mexico Bureau of Mines and Mineral Resources Circular, 180, 5-21.

Hyatt, A., 1894, Phylogeny of an acquired characteristic: Proceedings of the American Philosophical Society, 32 (143), 349-647.

Hyatt, A., 1903, Pseudoceratites of the Cretaceous, edited by T. W. Stanton: U.S. Geological Survey Monograph, 44, 351 p.

Izett, G.A., Cobban, W.A., Dalrymple, G.B., and Obradovich, J.D., 1998, 40Ar/39Ar age of the Manson impact structure, Iowa, and correlative impact ejecta in the Crow Creek Member of the Pierre Shale (Upper Cretaceous), South Dakota and Nebraska. Geological Society of America Bulletin, 110: 361-76.

Kauffman, E. G., Cobban, W. A. and Eicher, D. L., 1978, Albian through lower Coniacian strata, biostratigraphy and principal events, Western Interior United States, in Événements de la partie moyene du Crétacé; in Mid-Cretaceous events, Uppsala Nice 1975-1976: Annales du Muséum d'Histoire Naturelle de Nice, 4, 23.1-23.52 [1976 imprint].

Kauffman, E. G., Sageman, B. B., Kirkland, J. I., Elder, W. P., Harries, P. J. and Villamil, T., 1994, Molluscan biostratigraphy of the Cretaceous Western Interior basin, North America, in Caldwell, W. G. E., and Kauffman, E. G., eds., Evolution of 
the Western Interior basin: Geological Association of Canada Special Paper, 39, 397-434 [1993 imprint].

Kennedy, W. J. and Cobban, W. A., 1990, Cenomanian micromorphic ammonites from the Western Interior of the USA: Palaeontology, 33 (2), 379-422.

Kennedy, W. J. and Cobban, W. A., 1991a, Stratigraphy and interregional correlation of the Cenomanian-Turonian transition in the Western Interior of the United States near Pueblo, Colorado, a potential boundary stratotype for the base of the Turonian stage: Newsletters on Stratigraphy, 24 (1-2), 1-33.

Kennedy, W. J. and Cobban, W. A., 1991b, Coniacian ammonite faunas from the United States Western Interior: Special Papers in Palaeontology, 45, 96 p.

Kennedy, W. J. and Cobban, W. A., 1993, Ammonites from the Saratoga Chalk (Upper Cretaceous), Arkansas: Journal of Paleontology, 67 (3), 404-434.

Kennedy, W. J., Cobban, W. A. and Landman, N. H., 2001, A revision of the Turonian members of the ammonite Subfamily Collignoniceratinae from the United States Western Interior and Gulf Coast: Bulletin of the American Museum of Natural History, 267, 148 p.

Kennedy, W. J., Walaszczyk, I. and Cobban, W. A., 2000, Pueblo, Colorado, USA, candidate Global Boundary Stratotype Section and Point for the base of the Turonian Stage of the Cretaceous, and for the base of the Middle Turonian Substage, with a revision of the Inoceramidae (Bivalvia): Acta Geologica Polonica, 50 (3), 295-334.

Kennedy, W. J., Walaszczyk, I. and Cobban, W. A., 2005, The global boundary stratotype section and point for the base of the Turonian Stage of the Cretaceous; Pueblo, Colorado, U.S.A.: Episodes, v. 28, no. 2, p. 93-104.

Lamarck, J. B. P. A., de M. de., 1799, Prodrome d'un nouvelle classification des coquilles: Mémoires de Société Histoire Naturelle de Paris, 1, 63-91.

Landes, R. W., 1940, Paleontology of the marine formations of the Montana group, Pt. 2 of Geology of the southern Alberta plains: Geological Survey of Canada Memoir, 221, 129-217.

Landman, N. H. and Cobban, W. A., 2003, Ammonites from the upper part of the Pierre Shale and Fox Hills Formation of Colorado: American Museum Novitates, 3388, $45 \mathrm{p}$. 
Landman, N. H. and Waage, K. M. 1993, Scaphitid ammonites of the Upper Cretaceous (Maastrichtian) Fox Hills Formation in South Dakota and Wyoming: American Museum of Natural History Bulletin, 215, 257 p.

Laube, G. C. and Brüder, G., 1887, Ammoniten der böhmischen Kreide: Palaeontographica, 33, 217-239.

Mantell, G, 1822, The fossils of the South Downs, or illustrations of the geology of Sussex: Lupton Relfe, London, 327 p.

McArthur, J. M., Kennedy, W. J., Gale, A. S., Thirlwall, M. F., Chen, M., Burnett, J. and Hancock, J. M., 1992, Strontium isotope stratigraphy in the Late Cretaceous; intercontinental correlation of the Campanian/Maastrichtian boundary: Terra Nova, 4, 385-393.

McLearn, F. H., 1929, Cretaceous invertebrates, in Mesozoic paleontology of Blairmore region, Alberta: National Museum of Canada Bulletin, 58, 73-79.

Meek, F. B., 1871, Preliminary paleontological report, consisting of lists of fossils, with descriptions of some new types, etc, in Hayden, F. V., Preliminary report of the United States Geological Survey of Wyoming, and portions of contiguous territories, (being a second annual report of progress), 287-318.

Meek, F. B., 1876a, A report on the invertebrate Cretaceous and Tertiary fossils of the upper Missouri country: U.S. Geological Survey of the Territories (Hayden) Report, 9, 629 p.

Meek, F. B., 1876b, Descriptions of the Cretaceous fossils collected on the San Juan exploring expedition under Capt. J. N. Macomb, U.S. Engineers, in Macomb, J. N., Report of the exploring expedition from Santa Fe, New Mexico, to the Junction of the Grand and Green Rivers of the Great Colorado of the West in 1859: U. S Engineering Department, 119-133.

Meek, F. B. and Hayden, F. V., 1856, Descriptions of new species of Gastropoda and Cephalopoda from the Cretaceous formations of Nebraska Territory: Proceedings of the Academy of Natural Sciences of Philadelphia, 8, 70-72.

Meek, F. B. and Hayden, F. V., 1860, Descriptions of new organic remains from the Tertiary, Cretaceous, and Jurassic rocks of Nebraska: Proceedings of the Academy of Natural Sciences of Philadelphia, 12, 175-185.

Meek, F. B. and Hayden, F. V., 1861, Descriptions of new Lower Silurian (Primordial), Jurassic, Cretaceous, and Tertiary fossils collected in Nebraska Territory...; with some remarks on the rocks from which they were obtained: Academy of Natural Sciences of Philadelphia, Proceedings, 1861, 415-447. 
Meek, F. B. and Hayden, F. V., 1862, Descriptions of new Cretaceous fossils from Nebraska Territory, collected by the expedition... under the command of Lieutenant John Mullan...; Academy of Natural Sciences of Philadelphia, Proceedings, 1862, 21-28.

Merewether, E. A., Cobban, W. A. and Ryder, R. T., 1975, Lower Upper Cretaceous strata, Bighorn Basin, Wyoming and Montana, in Wyoming Geological Association Guidebook $27^{\text {th }}$ Annual field Conference, Geology and mineral resources of the Bighorn Basin, 1975: 73-84.

Merewether, E. A., Dolson, J. C., Hanson, W. B. and others, 1997, Cretaceous stratigraphy in a northeast-trending transect, northern Utah to south-central South Dakota: U.S. Geological Survey Geologic Investigations Map I-2609.

Morrow, A. L. 1935, Cephalopods from the Upper Cretaceous of Kansas: Journal of Paleontology, 9 (6), 463-473.

Morton, S. G., 1842, Description of some new species of organic remains of the Cretaceous group of the United States, with a tabular view of the fossils hitherto discovered in this formation: Journal of the Academy of Natural Sciences of Philadelphia, 8, 207-227.

Neumayr, M., 1875, Die Ammoniten der Kreide und die Systematik der Ammonitiden: Zeitschrift der Deutschen Geologischen Gesellschaft, 27, 854-892.

Nowak, J., 1911, Die Skaphiten, Part. 2 of Untersuchungen über die Cephalopoden der oberen Kreide in Polen: Bulletin International de l'Académie des Sciences. de Cracovie, Année 1911, ser. B, 547-589.

Obradovich, J. D., 1994, A Cretaceous time scale. In Caldwell, W.G.E., and Kauffman, E. G., eds., Evolution of the Western Interior Basin: Geological Association of Canada Special Paper, 39, 379-396 [1993 imprint].

Obradovich, J. D., Matsumoto, T., Nishida, T., and Inoue, Y., 2002, Integrated biostratigraphic and radiometric study on the lower Cenomanian (Cretaceous) of Hokkaido, Japan: Proceedings of the Japan Academy, v. 78, Ser. B, No. 6, 149153.

Orbigny, A. d', 1840-42, Paléontologie française: Terrains crétacé, v. 1 Céphalopodes: Paris, Masson, p. 1-120 (1840), p. 121-430 (1841), 431-662 (1842).

Orbigny, A. d', 1850-52, Prodrome de paléontologie stratigraphique universelle des animaux mollusques et rayonnés, 2: Paris, V. Masson, 428p. 
Owen, D.D., 1852, Report of a geological survey of Wisconsin, Iowa, and Minnesota and incidentally of a portion of Nebraska Territory: Philadelphia, Lippincott, Grambo \& Co., 638, p.

Parkinson, J., 1811, Organic remains of a former world, 3: London, J. Robson, 479 p.

Powell, J. D., 1963, Cenomanian-Turonian (Cretaceous) ammonites from Trans-Pecos Texas and northeastern Chihuahua, Mexico: Journal of Paleontology, 37 (2), 309322.

Reagan, A. B., 1924, Cretacic Mollusca of Pacific slope: Pan-American Geologist, 41, 179-190.

Reeside, J. B., Jr., 1927a, The scaphites, an Upper Cretaceous ammonite group: U.S. Geological Survey Professional Paper, 150-B, 21-40.

Reeside, J. B., Jr., 1927b, The cephalopods of the Eagle sandstone and related formations in the Western Interior of the United States: U.S. Geological Survey Professional Paper, 151, 87 p.

Reeside, J. B., Jr., 1927c, Cephalopods from the lower part of the Cody shale of Oregon Basin, Wyoming: U.S. Geological Survey Professional Paper, 150-A, 1-19.

Reeside, J. B., Jr., 1932, The Upper Cretaceous ammonite genus Barroisiceras in the United States: U.S. Geological Survey Professional Paper, 170-B, 9-29.

Reeside, J. B., Jr., 1944, Maps showing thickness and general character of the Cretaceous deposits in the Western Interior of the United States: U.S. Geological Survey Oil and Gas Investigations (prelim.) Map 10.

Reeside, J. B., Jr., 1957, Paleoecology of the Cretaceous seas of the Western Interior of the United States, Chapter 18 of Ladd, H. S., ed., Paleoecology: Geological Society America Memoir, 67, 505-542.

Reuss, A. E., 1845, Die Versteinerungen der böhmischen Kreideformation: Schweizerbart'sche Verlagsbuchhandlung, 58 p. Stuttgart.

Riccardi, A. C., 1983, Scaphitids from the Upper Campanian-Lower Maastrichtian Bearpaw Formation of the Western Interior of Canada: Geological Survey of Canada Bulletin, 334, 103 p.

Say, T., 1820, Observations on some species of zoophytes, shells, etc., principally fossil: American Journal of Science, $1^{\text {st }}$ ser., 2, 34-45.

Schlüter, C., 1871-72, Cephalopoden der oberen deutschen Kreide: Palaeontographica, $21,1-120$. 
Schneegans, D., 1943, Invértébrés du Crétacé supérieur du Damergou (Territoire du Niger), in Études stratigraphiques et paléontologiques sur le Bassin du Niger: French West Africa Direction Mines Bulletin, 7, 87-166.

Scott, G. R. and Cobban, W. A., 1959, So-called Hygiene group of northeastern Colorado. In Hahn, J. D., and Weimer, R. J., eds, Rocky Mountain Association of Geologists Eleventh Annual Field Conference Guidebook, Sand Wash and Piceance Basins, 124-131.

Scott, G. R. and Cobban, W. A., 1962, Clioscaphites saxitonianus (McLearn), a discrete ammonite zone in the Niobrara Formation of Pueblo, Colorado, in Short papers in geology and hydrology, articles 60-119, Geological Survey Research 1962: U.S. Geological Survey Professional Paper, 450-C, p. C85.

Scott, G. R. and Cobban, W. A., 1964, Stratigraphy of the Niobrara Formation at Pueblo, Colorado: U.S. Geological Survey Professional Paper, 454-L, 30 p.

Shumard, B.F., 1860, Descriptions of new Cretaceous fossils from Texas: Academy of Science St. Louis Transactions, v. 1, p. 590-610.

Spath, L. F., 1923, On the ammonite horizons of the Gault and contiguous deposits, in Great Britian Geological Survey summary of progress for 1922: 139-149.

Spath, L. F., 1926, On new ammonites from the English Chalk: Geological Magazine, 63 (740), 77-83.

Stanton, T. W., 1894, The Colorado formation and its invertebrate fauna: U.S. Geological Survey Bulletin, 106, 288 p. [1893 imprint].

Stanton, T. W., 1909, Succession and distribution of later Mesozoic invertebrate faunas in North America: Journal of Geology, 17 (5), 410-423.

Stephenson, L. W., 1953, Larger invertebrate fossils of the Woodbine formation (Cenomanian) of Texas: U.S. Geological Survey Professional Paper, 242, 226 p. [1952 imprint].

Stephenson, L. W. and Reeside, J. B., Jr. 1938, Comparison of Upper Cretaceous deposits of Gulf region and western interior region: American Association Petroleum Geologists Bulletin, 22 (12), 1629-1638.

Waage, K. M., 1975, Deciphering the basic sedimentary structure of the Cretaceous System in the Western Interior, in Caldwell, W.G.E., ed., The Cretaceous System in the Western Interior of North America: Geological Association of Canada Special Paper, 13, 55-81. 
Walaszczyk, I. and Cobban, W. A., 2000, Inoceramid faunas and biostratigraphy of the Upper Turonian-Lower Coniacian of the Western Interior of the United States: Special Papers in Palaeontology, 64, 118 p.

Walaszczyk, I., Cobban, W.A. and Harries, P. J., 2001, Inoceramids and inoceramid biostratigraphy of the Campanian and Maastrichtian of the Untied States Western Interior basin: Revue Paléobiologie, Genève, 20 (1), 117-234.

Walaszczyk, I., Cobban, W. A., and Odin, G. S., 2002, The inoceramid succession across the Campanian-Maastrichtian boundary: Bulletin of the Geological Society of Denmark, 49, 53-60.

Walaszczyk, I. and Cobban, W.A., 2006a (in press), Inoceramid fauna and biostatigraphy of the Middle Coniacian - Middle Santonian of the Pueblo section (SE Colorado, US Western Interior). Cretaceous Research.

Walaszczyk, I. and Cobban, W.A., 2006b, Inoceramids and biostratigraphy of the Middle-Upper Coniacian and Santonian inoceramids of the US Western Interior. Acta Geologica Polonica, 56 (3), 241-348.

Warren, P. S., 1930a, New species of fossils from Smoky River and Dunvegan formations, Alberta: Research Council of Alberta Geological Survey Report, 21, 57-98.

Warren, P. S., 1930b, Three new ammonites from the Cretaceous of Alberta: Transactions of the Royal Society of Canada, 3d ser., 24 (4), 21-26.

Warren, P. S., and Stelck, C.R., 1940, Cenomanian and Turonian faunas in the Pouce Coupe district, Alberta and British Columbia: Royal Society of Canada Transactions, 3d ser., 34 (4), 143-152.

White, C. A., 1878, Report on the geology of a portion of northwestern Colorado: U.S. Geological and Geographical Survey Territories (Hayden) Tenth Annual Report, 3- 60, map.

Whitfield, R. P., 1877, Preliminary report on the paleontology of the Black Hills, containing descriptions of new species of fossils from the Potsdam, Jurassic, and Cretaceous formations of the Black Hills of Dakota: U.S. Geographical and Geological Survey of the Rocky Mountain Region Report (Powell), 49 p.

Woods, H., 1912, A monograph of the Cretaceous Lamellibranchia of England; 2 (8): Palaeontographical Society [Monograph], 261-284.

Wright, C.W. and Kennedy, W. J., 1981, The Ammonoidea of the Plenus Marls and the Middle Chalk: Palaeontographical Society [London] Monograph, 148 p. 
USGS Open-File Report 2006-1250

Figure 1 A USGS Zonal Table for the Upper Cretaceous Middle Cenomanian - Maastrichtian of the Western Interior of the United States Based on Ammonites, Inoceramids, and Radiometric Ages

William A. Cobban, John D. Obradovich, Ireneusz Walaszcyk, and Kevin C. McKinney

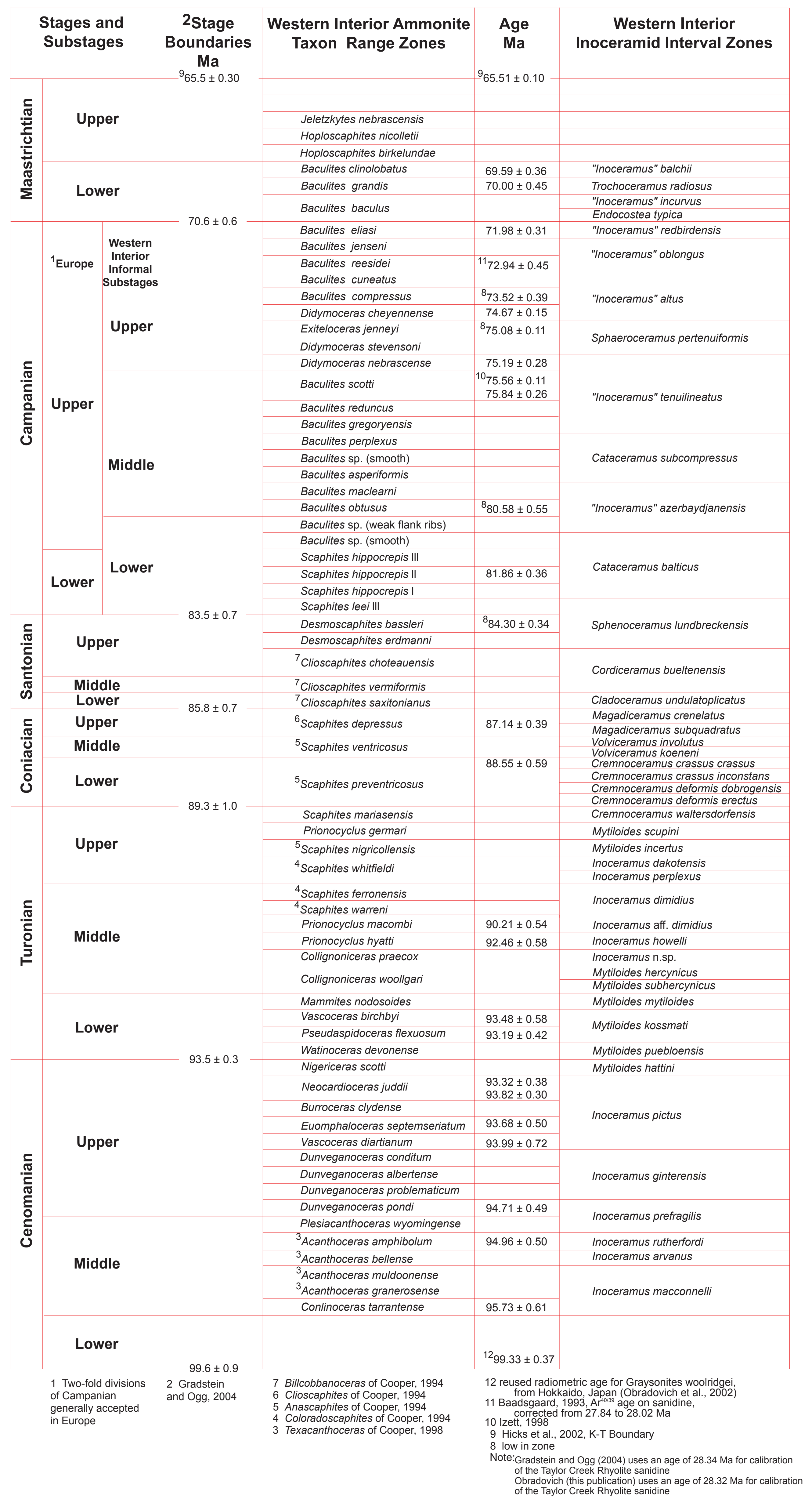

